\title{
240. Die Indikation zur Bluttransfusion bei Verbrennungen
}

\author{
M. ScHMOLKE-Tübingen
}

\section{The Indication for Blood Transfusion in Burns}

\begin{abstract}
Summary. In a clinical material of 300 patients with burns only one in six was given transfusions. They were restricted almost exclusively to cases with deep and extensive damage involving more than $15 \%$ of the body surface. Operations increase the demand for blood, additional injuries or other illnesses have little effect on it. A group of severely burnt patients showed more severe and more persistent anaemia, in spite of transfusions, than other patients who had not been given any blood. Indication for transfusion within the first $24 \mathrm{~h}$ is basically accepted. Even with the most cautious transfusion therapy, the compensation of anaemia due to burns is difficult.
\end{abstract}

Zusammenfassung. In einem Krankengut von 300 Verbrennungspatienten erhielt nur jeder 6. Transfusionen. Es sind fast ausschließlich tiefe Schäden in einer Ausdehnung von mehr als $15 \%$ der Körperoberfläche. (Operationen treiben den Blutbedarf in die Höhe, Nebenverletzungen und Nebenerkrankungen erhöhen ihn). Das Kollektiv der Sehwerverbrannten zeigt trotz der gegebenen Transfusionen eine stärkere und länger anhaltende Anämie als die blutfrei Behandelten. Die Indikation zur Transfusion in den ersten 24 Std wird grundsätzlich bejaht. Bei möglichst zurückhaltender Transfusionstherapie ist der Ausgleich der Verbrennungsanämie schwierig.

Der Vortrag 241, Versuch einer Therapie mit Aldactone in der 1. Phase der Verbrennungskrankheit von H. Fürstenberg* und J.-F. Bussmann-Mannheim, wurde nicht gehalten.

\section{Ein Beitrag zur Pathogenese und Therapie der Verbrennungsfrühphase im Säuglings- und Kleinkindesalter}

F. Truss * und K. Burkhardt-Göttingen

A Contribution on the Pathogenesis and Therapy of the Early Phase of Burns in Babies and Small Children

Summary. 435 ehildren with burns were admitted to the Surgical University Clinic, Göttingen, in the course of 15 years. $74 \%$ of them were less than 3 years old. Total mortality was $4.1 \%$. 16 of the 18 fatal burns occurred in the under-3 age group. Persistent infusion therapy occupies the most prominent position in treatment to counteract hypovolaemic shock which is often underestimated in children. A study of 144 babies with burns was intended to demonstrate the actual fluid requirements with optimal substitution in the early phase of burns. It was shown 